\title{
The First Detection and Phylogenetic Analysis of Bovine Astrovirus from Diarrheic Calves in Turkey
}

\author{
Turhan Turan, Hakan Ișıdan \\ Sivas Cumhuriyet University, Faculty of Veterinary Medicine, Department of Virology, 58140, Sivas, TURKEY
}

Geliş Tarihi / Received: 15.07.2018, Kabul Tarihi / Accepted: 07.08.2018

\begin{abstract}
A total of 127 stool samples (rectal swab) from diarrheic calves, up to one mouth of age, were collected during one year period (2014-16) from three cities (Sivas, Malatya and Elazığ) located central Turkey. 432 bp partial sequence of Nsplab gene were amplified. The PCR amplicons were purified and sequenced and deposited to GenBank. Sequence alignment and phylogenetic analysis being based on partial nucleotide sequences of Nsplab gene was constructed. As a result of RT-PCR study, we found that the $3.15 \%$ of fecal samples (4/127) were positive for diarrhea calves from Turkey. The neighbor-joinning tree of partial sequence of Nsplab gene (ORF1a) indicated that strains were substituted under three distinct lineage. None of our strains belonged to the Neuro1 lineage (lineage 3) of Bovine astrovirus which was isolated from bovine with neurological symptoms. On the other hand, while BAstVHT1-TUR strain was substituted under lineage $1 \mathrm{a}$, the other novel starts were lineage 2 . While the identity of analyzed sequences varies from 51.1 to $100 \%$, novel strains were calculated between 75.8 to $100 \%$ each other. As a result, we report the first detection and phylogenetic analysis of Bovine astrovirus from Turkey.
\end{abstract}

Key words: Bovine astrovirus, calf, phylogenetic analysis, Turkey.

\section{Türkiye'de İshalli Buzağılardan Bovine Astrovirus'un İlk Teşhisi ve Filogenetik Analizi}

\begin{abstract}
Özet: Orta Anadolu'da yer alan üç ilden (Sivas, Malatya ve Elazığ), 2014-16 yılları arasında toplam 127 dışkı örneği toplandı. Bovine astrovirus'un Nsplab geninin 432 bp kısmi bölgesi çoğaltıldı, dizi analizi yapıldı ve GenBank'a yüklendi. Sekans hizalaması ve filogenetik analizler yapılarak moleküler karakterizasyonu gerçekleştirildi. RT-PCR çalışmasının sonucuna göre örneklerin \%3,15'i (4/127) pozitif olarak tespit edildi. Kısmi Nsp1ab gen (ORF1a) bölgesinin neighbour-joinning yöntemiyle filogeni ağacı oluşturuldu. Buna göre izolatlarımızın hiçbiri sinirsel belirti gösteren sığırlardan izole edilen Neuro1 hattında (hat 3) yer almazken BAstV-HT1-TUR suşumuz hat 1a altında ve diğer suşlarımız ise hat 2 altında konumland1. Analiz edilen sekansların benzerliği \%51,1'den \%100'e varan oranlarda gerçekleşirken yeni suşların kendi arasındaki benzerlik oranının \%75,8'den \%100'e vardığı ortaya konuldu. Sonuç olarak, Bovine astrovirusun Türkiye'de ilk teşhisi ve filogenetik analizi rapor edilmiştir.
\end{abstract}

Anahtar sözcükler: Bovine astrovirus, buzağı, filogenetik analiz, Türkiye.

\section{Introduction}

Neonatal diarrhea of calves is the one of the significant health problem for the cattle industry. A numerous ethnology including as bacterial and viral agents (such as Bovine rotavirus; BRV, Bovine coronavirus; $\mathrm{BCoV}$, Bovine viral diarrhea virus; BVDV, etc.) have been shown that responsible for the diarrhea of calves [3, 8]. Additionally newly emerging viruses, such as Bovine torovirus (BToV), Bovine norovirus (BoNoV) and Bovine nebovirus $(\mathrm{BoNeV})$; also bovine picornaviruses: bovine enterovirus, Aichivirus B and hunnivirus A) were also reported as an enteric agent isolated from calves [3, $8,17,18]$.
The family Astroviridae consists of small (28$30 \mathrm{~nm}$ ), non-enveloped, single-stranded positivesense RNA viruses of approximately $7 \mathrm{~kb}$ in length. They have been classified into two genera, namely Mamastroviruses (MAstVs) and Avastroviruses (AAstVs), are known to infect mammalian and avian species, respectively [4]. Mamastroviruses have a broad host range including humans, mink, sheep, pigs, rats, marine mammals, dogs, cheetahs, roe deer, cattle and bats $[2,9,10,13,19,23,25]$.

Astroviruses are generally associated with either mild or severe enteric disease symptoms such as diarrhea and vomiting in a number of mammalian species [12]. The first reports in animals were from lambs and calves suffering from diarrhea [24, 27]. 
Subsequently, a bovine enteric virus antigenically related to the UK strain of BoAstV was isolated in Florida from a calf with diarrhea [28]. Bovine astrovirus was considered to be avirulent, as experimentally infected gnotobiotic calves remained clinically normal, although pathological studies on infected calves were not performed. Although calves experimentally infected with this astrovirus did not develop clinical disease, the virus caused cytopathology of the $\mathrm{M}$ cells of the dome epithelium covering the Peyer's patches [28].

It was originally concluded that in natural conditions, BoAstV does not seem to be directly associated with a severe diarrheic disease in calves $[5,25$, $27,28]$ and few controversial data are available on the prevalence of this infection. An astrovirus was isolated from diarrheic yaks from Tibet and also a diarrheic European roe deer (Capreolus capreolus), both are genetically related to BoAstV, suggesting that this virus could cross the species barrier to infect both cattle and roe deer or yaks $[7,25]$. On the other hand, although astroviruses were mainly found in relation to gastroenteritis in animals and humans so far, recently detected astrovirus infections were also related to encephalitis. [11, 15, 20, 21].

The existence of Bovine astrovirus is not yet reported from Turkey. The aim of the study is to observe bovine astroviruses from fecal samples of diarrheic calves in Turkey. In addition that, sequence and phylogenetic analysis of novel strains is also aimed.

\section{Materials and Methods}

Samples and RNA isolation: A total of 127 stool samples (rectal swab) from diarrheic calves, up to one mouth of age, were collected during one year period (2014-16) from three cities (Sivas, Malatya, and Elazığ) located central Turkey. During the sampling period collected stool samples transported to the laboratory quickly as possible and stored in minus $80^{\circ} \mathrm{C}$ deep freeze until they are submitted to the RNA isolation.

Fecal samples were 1/10 diluted in $1 \mathrm{M}$ phosphate buffered saline and centrifuged 5 minutes at $5000 \mathrm{rpm}$ to remove large cellular debris. After the centrifugation, supernatants were submitted to the nucleic acid extraction procedure according to the manufacturer's informations of GF-1 Viral Nucleic Acid Extraction Kit (Vivantis Technologies, Malaysia). Eluted nucleic acids were stored in $-80^{\circ} \mathrm{C}$ deepfreeze until use.

Reverse transcription polymerase chain reaction (RT-PCR): The cDNA synthesis was carried out in a $25 \mu \mathrm{l}$ final volume containing $4 \mu \mathrm{l}$ of RNA extract, $10 \mathrm{mM}$ deoxynucleoside triphosphate (dNTP), 2,5 $\mu 1$ 10x RT buffer (50mM Tris- $\mathrm{HCl}(\mathrm{pH}$ 8.3 at $\left.25^{\circ} \mathrm{C}\right), 75 \mathrm{mM} \mathrm{KCl}, 3 \mathrm{mM} \mathrm{MgCl} 2$ and $10 \mathrm{mM}$ DTT), 50ng of the random hexamer, $40 \mathrm{U}$ RNasin, 200 U M-MuLV Reverse-Transcriptase RNase H (Vivantis, Germany). The reverse transcription was performed at $37^{\circ} \mathrm{C}$ for $1 \mathrm{~h}$. Obtained cDNA samples were amplified with redesigned primer set of DPF/ DPR which was designed by Tse et al. [25] previously.

Table 1. Primers used in the study.

\begin{tabular}{llc}
\hline $\begin{array}{l}\text { Primer } \\
\text { Name }\end{array}$ & Sequences (5'-3') & References \\
\hline DPF & GAYTGGACBCGHTWTGATGG & Tse et al. [25] \\
DPFr & GAYTGGACHMGNTWYGAYGG* & This study \\
DPR & KYTTRACCCACATNCCAA & Tse et al. [25] \\
\hline
\end{tabular}

*Redesigned nucleotides indicated as bold lettering.

The PCR was conducted in a $50 \mu$ l final volume using $5 \mu 1$ of the RT reaction mixture as a template. The PCR mixture contained $5 \mu 1$ 10x PCR buffer, $10 \mathrm{mM} \mathrm{dNTP}, 10 \mathrm{pmol} / \mu \mathrm{l}$ of each sense/antisense primer, and 5 U of Taq DNA polymerase (Vivantis, Germany). The PCR was conducted under the following conditions: 1 cycle at $95^{\circ} \mathrm{C}$ for $2 \mathrm{~min}$ and 40 cycles of $94^{\circ} \mathrm{C}$ for $40 \mathrm{~s}$, (primer melting temperature $-5^{\circ} \mathrm{C}$ ) for $30 \mathrm{~s}$, and $72^{\circ} \mathrm{C}$ for $40 \mathrm{~s}$, followed by a final elongation step of $72^{\circ} \mathrm{C}$ for $10 \mathrm{~min}$. PCR products were analyzed by electrophoresis in $2 \%$ agarose gels stained with ethidium bromide.

Sequencing and phylogenetic analysis: The PCR amplicons were purified with a Wizard SV Gel and PCR Clean-Up System (Promega, Madison, WI) and sequenced using the BigDye Terminator Cycle Sequencing Kit (Applied Biosystems, Foster City, CA) on an automated sequencer (ABI 3100; Applied Biosystems, Foster City, CA). All of the sequenced products were used to obtain phylogenetic data. Partial sequences of nonstructural protein gene 
were compared with other Bovine astrovirus sequence datas which are online provided by National Center for Biotechnology Information (NCBI). Sequence alignment and phylogenetic analysis based on partial nucleotide sequences of $423 \mathrm{bp} \mathrm{Nsp1ab}$ gene was constructed with the use of a software, Unipro UGENE, version 1.21 [16].

\section{Results}

According to molecular detection study based on nonstructural protein gene (Nsp1ab) of Bovine astrovirus using DPF/DPR primer set, which was re- designed for this study, four fecal samples (4/127, $3.15 \%$ ) found to be positive. Partial sequences corresponding nonstructural protein gene were compared with other Bovine astrovirus sequence data which were online provided by National Center for Biotechnology Information (NCBI) (Table 2) by sequence alignment and phylogenetic analysis. While isolate BAstV/HT-1 was substituted under lineage 1a, BAstV/HT-2, 3 and 4 were substituted under lineage 2. None of novel BoAstV strains found to be related between the NeuroS1 which is a strain that isolated from a bovine with neurological symptoms.

Table 2. List of Bovine astrovirus sequences used in the molecular studies.

\begin{tabular}{|c|c|c|c|c|c|c|}
\hline & $\begin{array}{l}\text { GenBank } \\
\text { Accession No }\end{array}$ & Strain/Isolate Name & Host & $\begin{array}{c}\text { Year of } \\
\text { Isolation }\end{array}$ & Country & Reference \\
\hline$\overline{1}$ & KF233994.1 & NeuroS1 & Bovine & 2011 & USA & (20) \\
\hline 2 & KJ596489.1 & BoAstV-188-BRA & Bovine & 2012 & Brazil & $(25)$ \\
\hline 3 & KJ633790.1 & BoAstV-43-BRA & Bovine & 2007 & Brazil & $(25)$ \\
\hline 4 & KJ633791.1 & BoAstV-155-BRA & Bovine & 2009 & Brazil & $(25)$ \\
\hline 5 & KJ633794.1 & BoAstV-65-BRA & Bovine & 2007 & Brazil & (25) \\
\hline 6 & KJ633799.1 & BoAstV-267-BRA & Bovine & 2010 & Brazil & $(25)$ \\
\hline 7 & KR187171.1 & SC477 & Bovine & 2012 & UK & (24) \\
\hline 8 & KR187177.1 & SC491 & Bovine & 2012 & UK & (24) \\
\hline 9 & KR187180.1 & SC495 & Bovine & 2012 & UK & (24) \\
\hline 10 & KR187182.1 & SC497 & Bovine & 2012 & UK & (24) \\
\hline 11 & KR138600.1 & HC528 & Bovine & 2013 & UK & (24) \\
\hline 12 & KR138605.1 & HC1000 & Bovine & 2013 & UK & (24) \\
\hline 13 & KR138610.1 & HC1010 & Bovine & 2013 & UK & (24) \\
\hline 14 & KR138613.1 & HC1015 & Bovine & 2013 & UK & (24) \\
\hline 15 & KR138622.1 & HC1059 & Bovine & 2013 & UK & (24) \\
\hline 16 & KR138624.1 & HC1064 & Bovine & 2013 & UK & (24) \\
\hline 17 & KR138636.1 & SC362 & Bovine & 2012 & UK & (24) \\
\hline 18 & KR138659.1 & SC667 & Bovine & 2013 & UK & (24) \\
\hline 19 & KR138665.1 & SC680 & Bovine & 2013 & UK & (24) \\
\hline 20 & KJ476832.1 & BAstGX-J27 & Bovine & 2013 & China & (25) \\
\hline 21 & KJ476833.1 & BAstGX-G1 & Bovine & 2013 & China & $(25)$ \\
\hline 22 & HQ916313.1 & B18/HK & Bovine & 2010 & China & (10) \\
\hline 23 & HQ916316.1 & B76/HK & Bovine & 2010 & China & (10) \\
\hline 24 & HQ916317.1 & B76-2/HK & Bovine & 2010 & China & (10) \\
\hline 25 & LC047790.1 & BoAstV/JPN/Hokkaido11-55/2016 & Bovine & 2009 & Japan & $(15)$ \\
\hline 26 & LC047796.1 & BoAstV/JPN/Kagoshima1-7/2018 & Bovine & 2014 & Japan & $(15)$ \\
\hline 27 & LC047798.1 & BoAstV/JPN/Kagoshima2-3/2015 & Bovine & 2015 & Japan & $(15)$ \\
\hline
\end{tabular}




\begin{tabular}{llllccc}
\hline & $\begin{array}{l}\text { GenBank } \\
\text { Accession No }\end{array}$ & Strain/Isolate Name & Host & $\begin{array}{c}\text { Year of } \\
\text { Isolation }\end{array}$ & Country & Reference \\
\hline 28 & LC047799.1 & BoAstV/JPN/Kagoshima2-24/2015 & Bovine & 2015 & Japan & $(15)$ \\
29 & LC047800.1 & BoAstV/JPN/Kagoshima1-38/2017 & Bovine & 2015 & Japan & $(15)$ \\
30 & LC047801.1 & BoAstV/JPN/Kagoshima2-52/2015 & Bovine & 2015 & Japan & $(15)$ \\
31 & KX268310.1 & Bovine/BAstV-1/Sharkia/Egypt/2015 & Bovine & 2015 & Egypt & $(14)$ \\
32 & KX268312.1 & Bovine/BAstV-3/Sharkia/Egypt/2015 & Bovine & 2015 & Egypt & $(14)$ \\
33 & KT963071.1 & MAstV/Bov/ITA/2012/715 & Bovine & 2012 & Italy & Unpublished \\
34 & MG957147.1 & BAstV-HT1-TUR & Bovine & 2016 & Turkey & (This study) \\
35 & MG957148.1 & BAstV-HT2-TUR & Bovine & 2016 & Turkey & (This study) \\
36 & MG957149.1 & BAstV-HT3-TUR & Bovine & 2016 & Turkey & (This study) \\
37 & MG957150.1 & BAstV-HT4-TUR & Bovine & 2016 & Turkey & (This study) \\
\hline
\end{tabular}

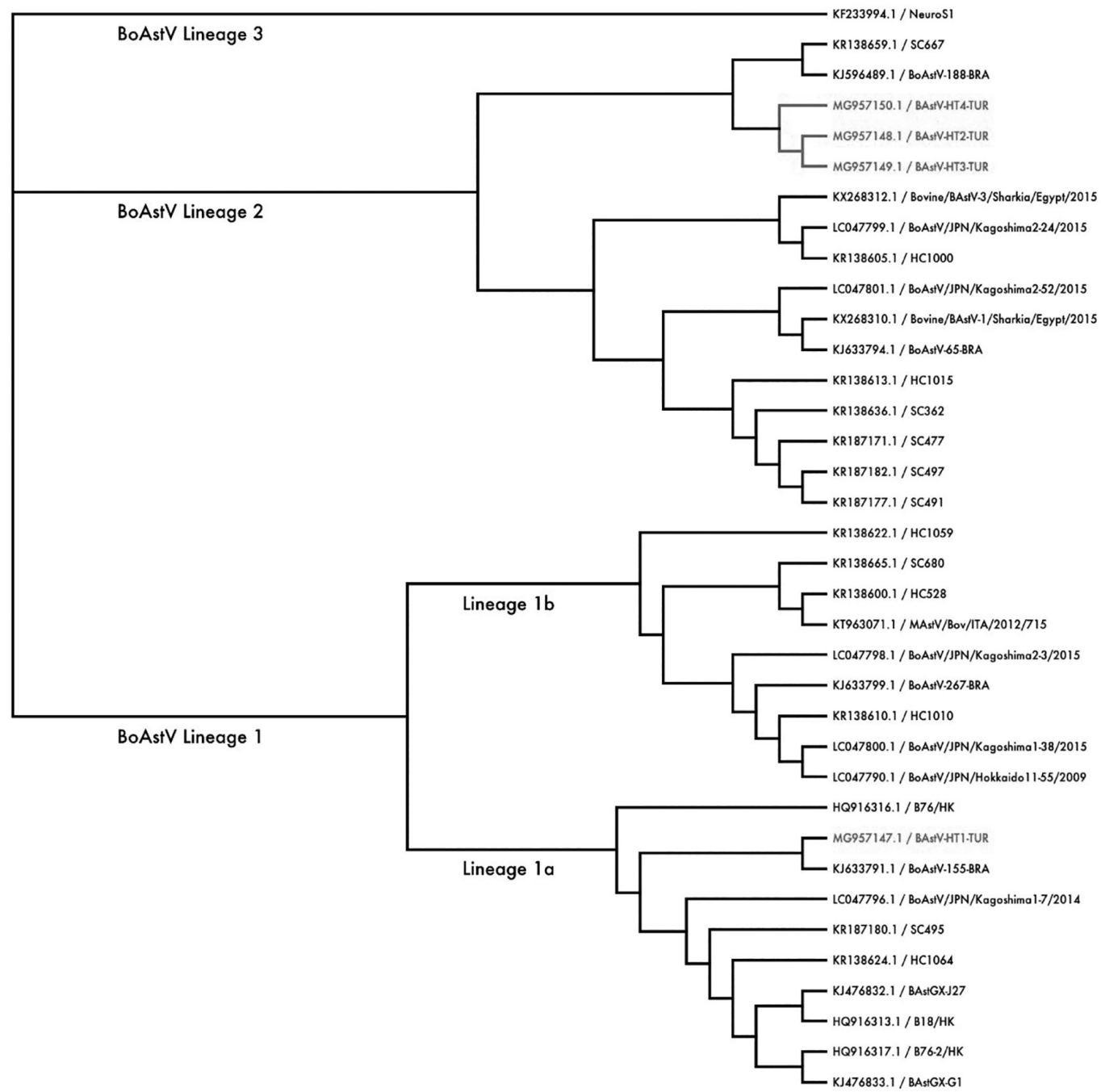

*Novel strains were illustrated as red color.

Figure 1. A phylogenetic bootstrap consensus tree of the partial Nsplab gene region of the Bovine astrovirus strains was made using the neighbor-joining method by using Unipro UGENE, version 1.21. [16]. 


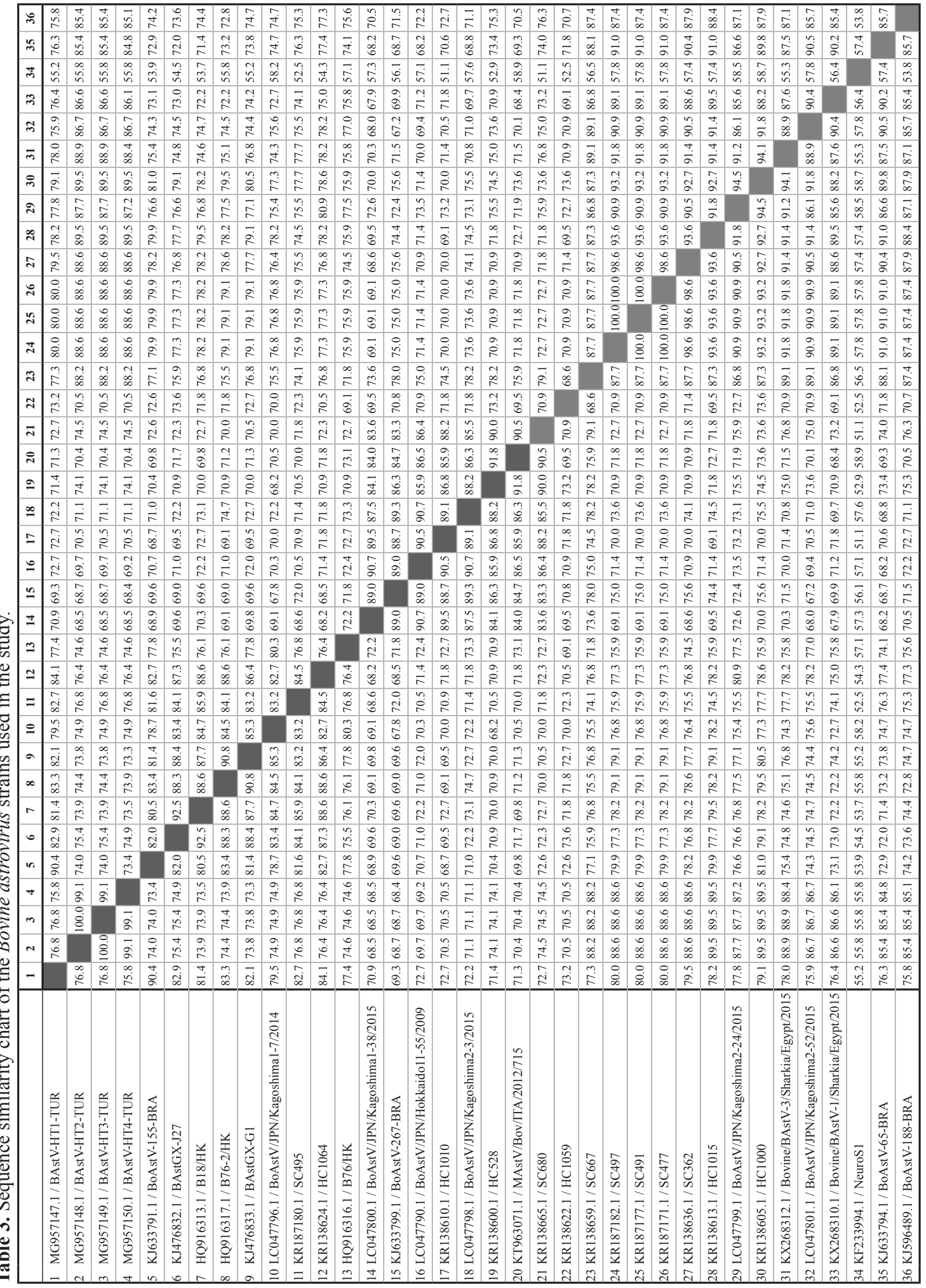




\section{Discussion}

The study reveals the first detection and phylogenetic analysis of BoAstV from diarrheic calves in Turkey. These fecal samples were previously studied for the presence of Bovine coronavirus (BCV), Bovine rotavirus $(\mathrm{BRV})$ and Bovine torovirus $(\mathrm{BToV})$ (unpublished), Bovine kobuvirus (BKV), Bovine enterovirus (BEV), Bovine hungarovirus $(\mathrm{BHuV})$ (in press), Bovine norovirus (BNoV) and Bovine nebovirus (BNeV) [26]. On the purpose of both detection and genetic characterization it was selected that $90 \mathrm{kDa}$ non-structural protein, nsp1a, that contains a conserved protease motifs similar to other viral $3 \mathrm{C}$-like proteases. Because of the diverse genetics of astroviruses, it is difficult to design precise detection tool by molecular basis. Multiple alignments of the BoAstV sequences, gathered from GenBank, indicated that it is necessity to check the detection primers by in-silico PCR method before using in a study. Thereby, we redesigned the forward primer of DPF as DPFr reported by Tse et. al., [25]. As a result of RT-PCR study, we found that the $3.15 \%$ of fecal samples $(4 / 127)$ were positive for diarrhea calves from Turkey.

There are several reports on bovine astroviruses from healthy and diarrheic calves and the prevalences vary between 10 to 74 percent according to research papers worldwide. BoAstV were reported as $74 \%(85 / 115)$ from both healthy and diarrheic calves from Scotland [22]. Alfred and coworkers were reported the BoAstV as $46.10 \%$ from diarrheic calves of 3 different cattle farm in China in 2013 [1]. In another study reports the detection of BoAstV were $32 \%$ from diarrheic calves from 2 cattle farm in Egypt in 2015 [14]. On the other hand, paper published by Nagai et al., [15] reports the astrovirus positivity at $10.27 \%$ from calves with and without diarrhea in Japan between 2009 and 2015.

The neighbor-joining tree of the partial Nsplab gene (ORF1a) of bovine astroviruses indicated that strains were substituted under three distinct lineage. None of our strains belonged to the Neurol lineage (lineage 3 ) of bovine astroviruses which were isolated from bovine with neurological symptoms. On the other hand, while BAstV-HT1-TUR strain were classified under lineage 1a, the other novel starts were lineage 2 (Figure 1). Similar trees were illustrated by researchers previously based on both partially or complete sequences of BoAstV $[1,6$, 14]. While the identity of analyzed sequences varies from 51.1 to $100 \%$, novel strains were calculated between 75.8 to $100 \%$ (Table 3 ).

As a result, to state the contribution of BoAstV on calf diarrhea more epidemiological study is needed. Also, definitive determination of bovine AstV as an enteric pathogen, either singly or in combination with another pathogen such as bovine rotavirus group A, would require viral isolation and experimental infections under natural conditions. We report the first detection and phylogenetic analysis of Bovine astrovirus from Turkey.

\section{References}

1. Alfred N, Liu H, Li ML, Hong SF, Tang HB, Wei ZZ, Chen Y, Li FK, Zhong YZ, Huang WJ, (2015). Molecular epidemiology and phylogenetic analysis of diverse bovine astroviruses associated with diarrhea in cattle and water buffalo calves in China. J Vet Med Sci, 77, 643-651. DOI:10.1292/jvms.14-0252

2. Atkins A, Wellehan JF Jr, Childress AL, Archer LL, Fraser WA, Citino SB, (2009). Characterization of an outbreak of astroviral diarrhea in a group of cheetahs (Acinonyx jubatus). Vet Microbiol, 136, 160-165, 2009. DOI:10.1016/j.vetmic.2008.10.035

3. Bartels CJM, Holzhauer M, Jorritsma R, et al (2010) Prevalence, prediction and risk factors of enteropathogens in normal and non-normal faeces of young Dutch dairy calves. Prev Vet Med 93:162-169. doi: 10.1016/j. prevetmed.2009.09.020

4. Benedictis PD, Schultz-Cherry S, Burnham A, Cattoli $\mathrm{G}$, (2011). Astrovirus infections in humans and animals - Molecular biology, genetic diversity, and interspecies transmissions. Infect Genet Evol, 11, 1529-1544. DOI:10.1016/j.meegid.2011.07.024

5. Bridger JC, Hall GA, Brown JF, (1984). Characterization of a calici-like virus (Newbury agent) found in association with astrovirus in bovine diarrhea. Infect Immun, 43, 133-138.

6. Candido M, Alencar ALF, Almeida-Queiroz SR, Buzinaro MG, Munin FS, de Godoy SHS, Livonesi MC, Fernandes AM, de Sousa RLM, (2015). Molecular detection and phylogenetic analysis of bovine astrovirus in Brazil. Arch Virol, 160, 1519-1525. DOI: 10.1007/ s00705-015-24008

7. Chen X, Zhang B, Yue H, Wang Y, Zhou F, Zhang Q, Tang C, (2015). A novel astrovirus species in the gut of yaks with diarrhoea in the Qinghai-Tibetan Plateau, 2013. J Gen Virol, 96, 3672-3680. DOI:10.1099/jgv.0.000303 
8. Cho Y il, Yoon KJ (2014) An overview of calf diarrhea infectious etiology, diagnosis, and intervention. J Vet Sci 15:1-17. doi: 10.4142/jvs.2014.15.1.1

9. Chu DK, Chin AW, Smith GJ, Chan KH, Guan Y, Peiris JS, Poon LL, (2010). Detection of novel astroviruses in urban brown rats and previously known astroviruses in humans. J Gen Virol, 91, 2457-2462. DOI:10.1099/vir.0.022764-0

10. Jonassen CM, Jonassen TO, Saif YM, Snodgrass DR, Ushijima H, Shimizu M, Grinde B, (2001). Comparison of capsid sequences from human and animal astroviruses. J Gen Virol, 82, 1061-1067. DOI:10.1099/0022-1317-825-1061

11. Li L, Diab S, Mc Graw S, Barr B, Traslavina R, Higgins R, Talbot T, Blanchard P, Rimoldi G, Fahsbender E, Page B, Phan TG, Wang C, Deng X, Pesavento P, Delwart E, (2013). Divergent astrovirus associated with neurologic disease in cattle. Emerging Infect Dis, 19, 1385-1392. DOI: $10.3201 /$ eid1909.130682

12. Mendez E, Arias CF, (2007). Astroviruses. Knipe DM, Howley PM eds. Fields virology. Lippincott Williams \& Wilkins, Philadelphia, USA, p.981-1000.

13. Monroe SS, (2005). Astroviridae. Carter MJ, Herrmann J, Mitchel JK Sanchez-Fauquier A eds. Virus taxonomy. Eighth report of the International Committee on Taxonomy of Viruses.Elsevier, Amsterdam, The Netherlands. P.859864.

14. Mohamed FF, Mansour FMG, El-Araby IE, Mor SK, Goyal SM, (2017). Molecular detection of enteric viruses from diarrheic calves in Egypt. Arch Virol, 162, 129-137. DOI: $10.1007 / \mathrm{s} 00705-016-3088-0$

15. Nagai M, Omatsu T, Aoki H, Otomaru K, Uto T, Koizumi M, Minami-Fukuda F, Takai H, Murakami T, Masuda T, Yamasato H, Shiokawa M, Tsuchiaka S, Naoi Y, Sano K, Okazaki S, Katayama Y, Oba M, Furuya T, Shirai J, Mizutani T, (2015). Full genome analysis of bovine astrovirus from fecal samples of cattle in Japan: identification of possible interspecies transmission of bovine astrovirus. Arch Virol, 160, 2491-2501. DOI: 10.1007/ s00705-015-2543-7

16. Okonechnikov K, Golosova O, Fursov M, and UGENE Team: Unipro UGENE, (2012). A unified bioinformatics toolkit. Bioinformatics, 28, 1166-1167. DOI: 10.1093/ bioinformatics/bts091

17. Pham NTK, Khamrin P, Nguyen TA, et al (2007) Isolation and Molecular Characterization of Aichi Viruses from Fecal Specimens Collected in Japan, Bangladesh,
Thailand, and Vietnam. J Clin Microbiol 45:2287-2288. doi: 10.1128/JCM.00525-07

18. Reuter G, Boros Á, Pankovics P (2011) Kobuviruses - a comprehensive review. Rev Med Virol 21:32-41. doi: 10.1002/rmv.677

19. Rivera R, Nollens HH, Venn-Watson S, Gulland FM, Wellehan JF Jr, (2010). Characterization of phylogenetically diverse astroviruses of marine mammals. J Gen Virol, 91, 166-173. DOI:10.1099/vir.0.015222-0

20. Schlotta K, Schulze C, Bilk S, Hanke D, Hoeper D, Beer M, Hoffmann B, (2016). Detection of a Novel Bovine Astrovirus in a Cow with Encephalitis. Transbound Emerg Dis, 63, 253-259. DOI:10.1111/tbed.12493

21. Selimovic-Hamza S, Bouzalas IG, Vandevelde M, Oevermann A, and Seuberlich T, (2016). Detection of astrovirus in historical cases of european sporadic Bovine encephalitis, switzerland 1958-1976. Front Vet Sci, 3, 91. DOI:10.3389/fvets.2016.00091

22. Sharp CP, Gregory WF, Mason C, deC Bronsvoort BM, Beard PM, (2015). High prevalence and diversity of bovine astroviruses in the faeces of healthy and diarrhoeic calves in South West Scotland. Vet Microbiol, 178, 70-76. DOI:10.1016/j.vetmic.2015.05.002

23. Smits SL, Van LM, Kuiken T, Hammer AS, Simon JH, Osterhaus AD, (2010). Identification and characterization of deer astroviruses. J Gen Virol, 91, 2719-2722. DOI: 10.1099/vir. 0.024067-0

24. Snodgrass DR, Gray EW, (1977). Detection and transmission of $30 \mathrm{~nm}$ virus particles (astroviruses) in faeces of lambs with diarrhoea. Arch Virol, 55, 287-291.

25. Tse H, Chan WM, Tsoi HW, Fan RY, Lau CC, Lau SK, Woo PC, Yuen KY, (2011). Rediscovery and genomic characterization of bovine astroviruses. J Gen Virol 92, 1888-1898. DOI:10.1099/vir.0.030817-0

26. Turan T, Işıdan H, Atasoy MO, İrehan B, (2018). Detection and molecular analysis of bovine enteric norovirus and nebovirus in Turkey. J Vet Res 62, 129-135. DOI:10.2478/ jvetres-2018-0021

27. Woode GN, Bridger JC, (1978). Isolation of small viruses resembling astroviruses and caliciviruses from acute enteritis of calves. J Med Microbiol, 11, 441-452. DOI: 10.1099/00222615-11-4-441

28. Woode GN, Pohlenz JF, Gourley NE, Fagerland JA, (1984). Astrovirus and Breda virus infections of dome cell epithelium of bovine ileum. J Clin Microbiol, 19: 623630. DOI: 0095-1137/84/050623-08\$02.00/0 